\title{
sciendo
}

\section{Healthcare-associated Clostridioides difficile infection during the COVID-19 pandemic in a tertiary care hospital in Romania}

\author{
ELIZA MANEA $^{1,2}$, RALUCA JIPA ${ }^{1,2}$, ALEXANDRU MILEA ${ }^{1}$, ANTONIA ROMAN ${ }^{1}$, GEORGIANA NEAGU ${ }^{1}$, \\ ADRIANA HRISTEA ${ }^{1,2}$
}

1 “Prof. Dr. Matei Bals”National Institute for Infectious Diseases, Bucharest, Romania

2 "Carol Davila" University of Medicine and Pharmacy, Bucharest, Romania

\begin{abstract}
Introduction. Information on healthcare-associated C.difficile infection (HA-CDI) in COVID-19 patients is limited. We aimed to assess the characteristics of HA-CDI acquired during and before the COVID-19 pandemic.

Methods. We conducted a retrospective study in a tertiary care hospital, in which since March 2020 exclusively COVID-19 patients are hospitalized. We compared HA-CDI adult patients hospitalized in March 2020-February 2021 with those hospitalized during the same period in 2017-2018.

Results. We found 51 cases during 2020-2021 (COVID-19 group), incidence 5.6/1000 adult discharge and 99 cases during 2017-2018 (pre-COVID-19 group), incidence 6.1/1000 adult discharge $(\mathrm{p}=0.6)$. The patients in COVID-19 group compared to pre-COVID-19 group were older (median age 66 vs 62 years), with similar rate of comorbidities, but with higher rate of cardiovascular diseases $(62.7 \%$ vs $42.4 \%)$ and less immunosuppression (21.6\% vs $55.6 \%)$, they had a higher proton pump inhibitors use (94.1\% vs 32.3\%), and a longer hospitalization (median 19 vs 14 days).

Eighty-five (85.9\%) patients in pre-COVID-19 group versus $44(86.3 \%)$ patients in COVID-19 group received antimicrobial treatment - mainly cephalosporins $(34,1 \%)$, quinolones $(22,3 \%)$ and glycopeptides $(21,1 \%)$ in pre-COVID-19 group and mainly cephalosporins and macrolides $(63,6 \%$ each) in COVID-19 group. We found four HA-CDI-related deaths in pre-COVID-19 group and none in the COVID-19 group.

Conclusions. The HA-CDI incidence in COVID-19 group did not change versus the same period of time during 2017-2018. The antibiotic use was the most important factor associated with HA-CDI. We identified a high use of broad-spectrum antibiotics despite the lack of empirical antimicrobial recommendations in COVID-19.
\end{abstract}

Key words: Clostridioides difficile infection, COVID-19, healthcare associated, risk factors.

\footnotetext{
What is important?

Information on healthcare-acquired C.difficile in COVID-19 patients is limited and C.difficile infection remains a worrying issue, and an emerging topic. We found that antibiotic use seems to be the most important factor associated with CDI and our data emphasize the need for rational use of antibiotics and for ongoing attention regarding CDI in COVID-19 patients.
}

\section{INTRODUCTION}

COVID-19 predominantly includes pulmonary symptoms, but gastrointestinal manifestations have also been noted, the most likely mechanism being the presence of Angiotensin Converting Enzyme 2 receptors on gut epithelial cells, a known target for viral binding and entry. Diarrhea, in particular, has been reported in up to $34 \%$ of individuals in cohorts from the USA. Furthermore, some authors suggested that the intestinal inflammation due to
COVID-19 could predispose individuals to coinfection with other gastrointestinal pathogens. Such infections, particularly Clostridioides difficile, can cause a significant burden to infected individuals [1].

C.difficile remains among the top five urgent infectious threats and is the most common pathogen among health care-associated (HA) infections [2]. Although preventive contact precautions are recommended, there are no sufficient data on their effectiveness for its prevention [3]. C.difficile infection (CDI) is 
commonly associated with the use of broadspectrum antibiotics, inadequate infection control and hospital overcrowding. Changes in gut microbiota after antibiotic treatment create a metabolic environment that favors C.difficile germination and colonization. Nearly every antibiotic has been implicated in the development of CDI, including the drugs used for its treatment. Azithromycin has been proposed as a potential therapy for the treatment of SARS-CoV-2 pneumonia and has been widely used since the beginning of the COVID-19 pandemic, given its antiviral and immunomodulatory activity [4]. Apart from antibiotic use, there are other factors associated with CDI, including higher age $(>65$ years), longer hospitalization, the use of proton pump inhibitors, comorbidities, chemotherapy, chronic kidney disease, abdominal surgery $[5,6,7]$. Use of broad-spectrum antimicrobial therapy was widely reported with over 70\% of COVID-19 cases receiving antibacterial therapy despite current evidence which does not support a high rate of bacterial respiratory co-infections in patients with SARS-CoV-2 infection [8]. The anxiety and the absence of antiviral treatments with proven efficacy are probable some of the contributors to the widespread and overuse of antibiotics.

To date, there is no clear picture of the burden of CDI in COVID-19 patients. We wondered if the infection prevention and control measures related to COVID-19, implemented in our institution, would impact healthcare-associated CDI (HA-CDI) cases. The aim of this study was to assess the CDI during the COVID-19 pandemic. The primary objective of this study was to assess the incidence of HA-CDI during the COVID-19 pandemic. The secondary objective was to identify the characteristics of the HA-CDI patients coinfected with SARS-CoV-2, compared to HA-CDI cases before the COVID-19 pandemic.

\section{MATERIAL AND METHODS}

\section{Study design and patients}

We conducted a retrospective cohort study in a tertiary care hospital in Romania. The hospital was transformed in a first line COVID-19 healthcare unit since March 2020, in which only COVID-19 patients were hospitalized. The diagnosis of SARS-CoV-2 infection was confirmed by positive real time-polymerase chain reaction (RT-PCR) from nasopharyngeal swab.
We included the adult patients diagnosed with HA-CDI acquired during hospitalization in our institution for COVID-19 between March 2020 and February 2021. Patients were identified by reviewing the microbiology records. Diagnosis of CDI was based on clinical symptoms (presence of diarrhoea) and detection of the gene coding for $C$. difficile toxin in stool using PCR and/or toxin detection. Diarrhoea was defined according to ESCMID guidelines as loose stools corresponding to Bristol stool chart types 5-7, plus a stool frequency of at least three loose stools within 24 hours [9]. We included HA-CDI defined as a case of CDI with onset of symptoms at least 48 hours following admission. We did not include patients with onset of symptoms in the community within 4 weeks following discharge from our healthcare facility, as commonly defined [10]. HA-CDI incidence was defined as CDI cases diagnosed $\geq 48$ hours after hospital admission per 1000 total discharges.

This cohort of CDI in COVID-19 patients was compared with another cohort of adult patients, with HA-CDI acquired during hospitalization in our institution between March 2017 and February 2018.

Demographic and clinical data (CDI onset and clinical characteristics, COVID-19 onset and characteristics, laboratory data, antimicrobial treatments before and after the diagnosis of CDI as well as the patient's outcome) were recorded. The patients included in the study were classified according to Charlson comorbidity score and ATLAS severity score (based on age, treatment with systemic antibiotics, leucocyte count, albumin and temperature). We also assessed the severity of CDI patients according to the Society for Healthcare Epidemiology of America (SHEA), defined by the presence of leukocytosis of $15 \times 10^{9} / \mathrm{L}$ or higher, or serum creatinine level over $1.5 \mathrm{mg} / \mathrm{dL}$ [11]. The study was approved by the hospital Ethics Committee.

\section{Statistical analysis}

The data collected were analysed using the statistical analysis software package SPSS 23.0 (IBM SPSS, Chicago, IL, USA). Differences between groups were analysed using the MannWhitney U test for continuous variables and the chi-square test or Fisher's exact test for dichotomous variables as appropriate and $p<0.05$ was considered significant. 


\section{RESULTS}

We identified 99 cases of HA-CDI acquired during hospitalization in our institution during 20172018 (pre-COVID-19 group), the incidence of HACDI being 6.1/1000 adult discharge in this period of time. During 2020-2021 (COVID-19 group), the incidence of HA-CDI was 5.6/1000 adult discharge $(\mathrm{p}=0.6)$, with 51 patients with CDI acquired during hospitalization for SARS-CoV-2 infection.

Eighty-six (86.9\%) CDI cases diagnosed in pre-COVID-19 group were first episodes of CDI, while in COVID-19 group were diagnosed 49 (96.1\%) first episodes of CDI ( $\mathrm{p}=0.09)$.

The diagnosis of CDI in the pre-COVID-19 group versus COVID-19 group was performed only by PCR in $79(79.8 \%)$ versus $12(23.5 \%)$ cases $(\mathrm{p}<0.001)$ and only by toxin detection in stool in 13
$(13.1 \%)$ versus $25(49 \%)(\mathrm{p}<0.001)$. Both diagnostic methods were performed in $7(7.1 \%)$ patients in the pre-COVID-19 group and in $14(27.5 \%)$ patients in the COVID-19 group ( $\mathrm{p}=0.001)$.

The ribotype 027 was found in 64 (74.4\%) out of a total of 86 patients with PCR detection of CDI in pre-COVID-19 group and in $25(96.1 \%)$ out of a total of 26 patients with PCR performed in COVID-19 group ( $\mathrm{p}=0.03$ ).

The baseline characteristics of the patients are summarized in Table 1. Overall, the patients with HA-CDI in the COVID-19 group were older, with similar rate of comorbidities, but with higher rate of cardiovascular disease and with significantly less immunosuppression. Also, in COVID-19 group was recorded a higher use of proton pump inhibitors compared to patients from the pre-COVID-19 group.

Table 1

Characteristics of patients. Data are expressed as number of patients (percentage) except where specified

\begin{tabular}{|c|c|c|c|}
\hline & $\begin{array}{l}\text { Pre-COVID-19 CDI group } \\
\qquad \mathrm{N}=99\end{array}$ & $\begin{array}{l}\text { COVID-19 CDI group } \\
\qquad \mathrm{N}=51\end{array}$ & $\mathbf{p}$ \\
\hline Male sex & $47(47.5)$ & $28(54.9)$ & 0.3 \\
\hline Age in years (Median, IQR) & $62(39-76)$ & $66(60-72)$ & 0.02 \\
\hline Median Charlson index (IQR) & $4(2-6)$ & $4(2-5)$ & 0.6 \\
\hline Proton pump inhibitors use & $32(32.3)$ & $48(94.1)$ & $<0.001$ \\
\hline Immunosuppressive condition & $55(55.6)$ & $11(21.6)$ & $<0.001$ \\
\hline \multicolumn{4}{|l|}{ Underlying disease } \\
\hline $\begin{array}{lll}\text { Cardiovascular } & \text { disease } & \text { and/or } \\
\text { hypertension } & & \end{array}$ & $42(42.4)$ & $32(62.7)$ & 0.02 \\
\hline Solid malignancy & $7(7.07)$ & $5(9.8)$ & 0.5 \\
\hline Hematologic malignancy & $3(3.03)$ & 0 & 0.5 \\
\hline Diabetes mellitus & $17(17.1)$ & $11(21.5)$ & 0.5 \\
\hline Chronic kidney disease & $6(6.06)$ & $5(9.8)$ & 0.5 \\
\hline Chronic respiratory disease & $6(6.06)$ & $4(7.8)$ & 0.7 \\
\hline Liver failure & $7(7.07)$ & $1(1.9)$ & 0.2 \\
\hline HIV infection & $12(12.1)$ & $1(1.9)$ & 0.06 \\
\hline Median ATLAS score (IQR) & $3(2-4)$ & $3(1-6)$ & 0.4 \\
\hline Leukocytosis $\geq 15000$ cells $/ \mathrm{mL}$ & $23(23.2)$ & $18(35.3)$ & 0.1 \\
\hline Serum creatinine $>1.5 \mathrm{mg} / \mathrm{dL}$ & $17(17.2)$ & $5(9.8)$ & 0.2 \\
\hline \multicolumn{4}{|l|}{ CDI treatment } \\
\hline Metronidazole & $15(15.2)$ & $1(2)$ & 0.01 \\
\hline
\end{tabular}




\begin{tabular}{|l|l|l|l|}
\hline Vancomycin & $93(93.9)$ & $51(100)$ & 0.1 \\
\hline Vancomycin+ Tigecycline & $13(13.1)$ & $14(27.5)$ & 0.03 \\
\hline Duration of treatment (Median, IQR) & & $5(5-5)$ & 0.3 \\
\hline Metronidazole & $9(5-10)$ & $10(7-14)$ & 0.5 \\
\hline Vancomycin & $10(7-14)$ & $7(5-10)$ & 0.7 \\
\hline Tigecycline & $6(3-10)$ & $19(15-24)$ & 0.7 \\
\hline Length of hospital stay (Median, IQR) & $14(10-24)$ & & \\
\hline
\end{tabular}

According to SHEA guidelines definition of severity, we found $40(40.4 \%)$ severe CDI cases in the pre-COVID-19 group and $23(45 \%)$ severe CDI cases in the COVID-19 group ( $p=0.6)$. In both two groups we did not find cases of fulminant colitis or toxic megacolon, but in the pre-COVID-19 group we found four deaths attributable to CDI. There was no CDI-related death recorded in the COVID-19 group. Regarding the outcome, in the pre-COVID-19 group versus the COVID-19 group: 87 (87.9\%) versus $45(88.2 \%)$ patients recovered and were discharged $(\mathrm{p}=1), 2(2 \%)$ versus $2(3.9 \%)$ patients were transferred to another healthcare unit $(\mathrm{p}=0.6)$ and $10(10.1 \%)$ versus $4(7.8 \%)$ patients died, $\mathrm{p}=0.7$.

The mean length of hospital stay in HA-CDI was similar in both groups (20 days), but longer compared with the overall mean lengths of stay in non-CDI patients in the two period of time: 8 days during 2017-2018 and 15 days during 2020-2021.
Out of the 51 patients with coinfection C.difficile and SARS-CoV-2, 2 (3.9\%) had a mild form of COVID-19, 19 (37.5\%) had moderate disease, $27(52.9 \%)$ had severe disease and $3(5.9 \%)$ had critical disease. The diagnosis of CDI was established in these patients after a median of 15 days (IQR 10-20) after COVID-19 onset.

Recent antimicrobials use was noted in 85 (85.9\%) patients in pre-COVID-19 group versus 44 (86.3\%) patients in COVID-19 group, $\mathrm{p}=0.9$ (data related to antimicrobials classes are summarized in Table 2). In both groups, the most common antimicrobial class was beta-lactam, specifically cephalosporins for the COVID-19 group. Macrolides (specifically azithromycin) were the second most frequently used class during the COVID-19 pandemic period. In the pre-COVID-19 group, the second most frequently antimicrobials used were quinolones and glycopeptides. A higher rate of association of more than two antimicrobials was noted among the patients with COVID-19.

Table 2

Antimicrobials administered before CDI diagnosis. Data are expressed as number of patients (percentage)

\begin{tabular}{|c|c|c|c|}
\hline & Pre-COVID-19 CDI group N=85 & $\begin{array}{l}\text { COVID-19 CDI group } \\
\qquad \mathrm{N}=44\end{array}$ & $\mathbf{p}$ \\
\hline Beta-lactam & $62(72.9)$ & $34(72.2)$ & 0.8 \\
\hline Cephalosporins & $29(34.1)$ & $28(63.6)$ & 0.002 \\
\hline Carbapenems & $20(23.5)$ & $11(25)$ & 0.9 \\
\hline Macrolides & $4(4.7)$ & $28(63.6)$ & $<0.001$ \\
\hline Quinolones & $19(22.3)$ & $2(4.5)$ & 0.005 \\
\hline Glycopeptides & $18(21.1)$ & $2(4.5)$ & 0.001 \\
\hline Cyclines & $3(3.5)$ & $1(2.2)$ & 0.6 \\
\hline Oxazolidinone (Linezolid) & $9(10.5)$ & $7(15.9)$ & 0.4 \\
\hline $\begin{array}{l}\text { Association of more than } 2 \\
\text { antimicrobials }\end{array}$ & $13(15.2)$ & $10(22.7)$ & 0.06 \\
\hline
\end{tabular}




\section{DISCUSSION}

Most accommodation in our institution, which have been admitting only COVID-19 patients since March 2020, is composed of three bed rooms and a shared bathroom/room. Since the beginning of the pandemic, the use of protective personal equipment consisting of surgical masks, latex gloves, face shields and disposable medical coats, was implemented and a greater attention has been given to surfaces disinfection, mainly with hypochlorite-based agents known to be effective for killing spores produced by $C$.difficile too. Also, no visits of the relatives to hospitalized patients were allowed. The health care workers habits regarding the infection control standard precautions have remained similar during the COVID-19 pandemic with the prior time. Nevertheless, less attention might have been given to the recommendations for CDI control and prevention, including hand washing and the use of a supplementary disposable coat. In this context, we noticed a similar incidence of HA-CDI cases during the COVID-19 pandemic compared to the same period of time before the pandemic.

In contrast to our findings, a recently published retrospective study found a lower HACDI incidence during the pandemic (between March-June 2020) compared to the same period in 2017 (OR=2.98; $\mathrm{p}=0.002), 2018 \quad(\mathrm{OR}=2.27$; $\mathrm{p}=0.02)$ and $2019(\mathrm{OR}=2.07 ; \mathrm{p}=0.04)$, but the same study showed also a higher HA-CDI incidence among the COVID-19 departments compared to Covid-19 free wards, suggesting SARS-CoV-2 infection as a possible risk factor for CDI [3]. On the other hand, a retrospective case-control study performed in Italian hospitals between February and July 2020 showed an HACDI incidence rate of 4.4 per 10,000 patient days - this value being within the range of incidence observed in previous reports performed before the COVID-19 pandemic in Italy and in Europe [12]. Moreover, in a center from the USA Sandhu et al. also reported an increase of the rate of CDI from $3.32 / 10,000$ patient-days to $3.60 / 10,000$ patientdays during January-April 2020 [13].

We also noticed in our study an overuse of antibiotics, with $86.3 \%$ of COVID-19 patients receiving antibiotics before the CDI diagnose. Paradoxically, this high rate of antimicrobials used during the COVID-19 pandemic - for the management of a viral infection (with only a minority of COVID-19 patients having confirmation of bacterial infections), is similar with the pre-COVID-19 pandemic data, with $85.9 \%$ patients receiving antibiotics before the CDI diagnose during 2017-2018, when the hospital was not exclusively dedicated to a viral infection. Also, tigecycline was more frequently associated to vancomycin for HA-CDI treatment in the COVID19 group, mainly for its use as a broad-spectrum antibiotic for bacterial pneumonia, possibly associated with a lower risk for aggravating CDI than other broad-spectrum antibiotics. This overuse of antibiotics might explain the unchanged HACDI incidence rates during the COVID-19 pandemic, despite a correct use of the protective personal equipment and patient's isolation.

The two groups were similar regarding the use of betalactams, but in the COVID-19 group was noticed a higher use of cephalosporins and macrolides, while in the pre-COVID-9 group the most frequent used antibiotics, after betalactams, were quinolones and glycopeptides.

Data from a systematic review including 3506 COVID-19 patients showed that bacterial infection was more common in critically ill patients and most patients with COVID-19 (71.9\%, 95\%CI $56.1-87.7 \%)$ received antibiotics, mostly broadspectrum agents. This review reported bacterial coinfection in $3.5 \%$ of patients (95\%CI $0.4-6.7 \%$ ) and bacterial secondary infection in $14.3 \%$ of patients (95\%CI 9.6-18.9\%). Overall, reported bacterial infection was 6.9\% (95\% CI $4.3-9.5 \%)$, but varied slightly by patient population, ranging from $5.9 \%$ in hospitalized patients to $8.1 \%$ in critically ill patients [14]. In our COVID-19 group, $52.9 \%$ were severe cases of COVID-19, $5.9 \%$ were critical forms of COVID-19 and 7\% cases had documented bacterial infection.

Regarding the characteristics of the two HACDI groups compared in our study, we noticed that during the COVID-19 pandemic the majority of cases were infected with C.difficile ribotype 027 . More CDI cases in COVID-19 group were diagnosed only by toxin detection in stool compared with the pre-COVID-19 group, in which PCR detection of C.difficile was performed in the majority of patients, because during the COVID-19 pandemic the molecular techniques lab was primarily dedicated to SARS-CoV-2 testing.

Moreover, the COVID-19 patients were older, with higher rate of cardiovascular diseases, with higher use of proton pump inhibitors, but with less immunosuppression.

The CDI treatment was comparable between the two groups, most of the patients 
receiving oral vancomycin (similar duration), but with a significant lower use of metronidazole in COVID-19 patients and with a higher use of tigecycline in these patients (as empirical antimicrobial treatment for the association of alveolar pneumonia in these cases). Both groups were similar regarding the CDI severity, according to SHEA guidelines definition of severity, but with four deaths related to CDI recorded in the pre-COVID-19 group.

The main limitation of our study, due to its retrospective nature, is the possibility of underestimating the actual incidence of HA-CDI in both groups, because we did not assess the HACDI cases with community onset that might had appeared after discharge; the patients were lost from follow-up after discharge.

In conclusion, we found no significant differences regarding the HA-CDI incidence in our institution during the COVID-19 pandemic compared to data we recorded between 2017-2018. The antibiotic use seems to be the most important factor associated with CDI and measures in place to prevent a respiratory tract infection did not impact the CDI incidence. Our study also identified a high use of broad-spectrum antibiotics even though there are no recommendations of empirical antimicrobial administration for SARS-CoV-2 infection. These results underline the importance of infection prevention and control, but also of rational use of antibiotics, in the management of COVID-19 patients, not only because of CDI risk, but also because we might expect an increasing antimicrobial resistance in the context of an unnecessary use of broad spectrum antimicrobials. There is clear need for ongoing attention regarding CDI in COVID-19 patients.

Introducere. Datele privind infecția cu C.difficile asociată asistenței medicale (ICD-AAM) la pacienții cu COVID-19 sunt limitate. Scopul studiului a fost evaluarea ICD-AAM din timpul și anterior pandemiei COVID-19.

Metode. Am realizat un studiu retrospectiv într-un spital de asistență terțiară, unde din Martie 2020 au fost internați exclusiv pacienți cu COVID-19. Am comparat pacienții adulți cu ICD-AAM spitalizați între martie 2020 - februarie 2021 cu cei spitalizați în aceeași perioadă, între 2017-2018.

Rezultate. S-au identificat 51 cazuri între 2020-2021 (grupul COVID-19), incidența 5,6/1000 adulți externați și 99 cazuri între 2017-2018 (grupul pre-COVID19), incidența 6,1/1000 adulți externați $(p=0.6)$. Pacienții din grupul COVID-19, comparativ cu grupul pre-COVID-19, au fost mai vârstnici (mediana 66 vs 62 ani), cu o rată similară de comorbidități, dar mai mare a bolilor cardiovasculare $(62,7 \%$ vs 42,4\%) și mai mică de imunosupresie (21,6\% vs 55,6\%), cu consum mai mare de inhibitori de pompă de protoni $(94,1 \%$ vs $32,3 \%)$ și cu o spitalizare mai lungă (mediana 19 vs 14 zile). Optzeci și cinci (85,9\%) pacienți din grupul pre-COVID-19 vs 44 (86,3\%) din grupul COVID-19 au primit antibioterapie - preponderent cefalosporine (34,1\%), chinolone (22,3\%), glicopepetide $(21,1 \%)$ in grupul preCOVID-19 și preponderent cefalosporine și macrolide (fiecare 63,6\%) în grupul COVID-19. S-au identificat 4 decese asociate ICD-AAM în grupul pre-COVID-19 și niciunul în grupul COVID-19.

Concluzii. Incidența ICD-AAM în grupul COVID-19 nu s-a modificat comparativ cu perioada 2017-2018. Utilizarea antibioticelor a fost cel mai important factor asociat ICD-AAM. S-a identificat o utilizare crescută a antibioticelor cu spectru larg, deși nu există recomandări pentru antibioterapia empirică în COVID-19.

Correspondence to: Eliza Manea, M.D., "Prof Dr Matei Bals" National Institute of Infectious Diseases; no 1 Calistrat Grozovici, street, sect 2, postal code: 021105, Bucharest, Romania

Mobile phone: +40740234827

E-mail: elizamanea10@yahoo.com

Conflict of interest disclosure: The authors declare that there are not conflicts of interest.

Funding: This research did not receive any specific grant from funding agencies in the public, commercial, or not-for-profit sectors. 


\section{REFERENCES}

1. REDD WD, ZHOU JC, HATHORN KE, MCCARTY TR, BAZARBASHI AN, THOMPSON CC, et al. Prevalence and characteristics of gastrointestinal symptoms in patients with SARS-CoV-2 infection in the United States: A multicenter cohort study. Gastroenterology. 2020; 159(2): 765-7.

2. HAQUE M, SARTELLI M, MCKIMM J, ABU BAKAR M. Health care-associated infections - an overview. Infection and Drug Resistance. 2018;11:2321-33.

3. BENTIVEGNA E, ALESSIO G, SPUNTARELLI V, LUCIANI M, SANTINO I, SIMMACO M, et al. Impact of COVID-19 prevention measures on risk of health care-associated Clostridium difficile infection. American Journal of Infection Control. 2020;1-3.

4. ESNAL DE, ONTIYUELO CM, ROUCO MEN, CUSCO MA, FERRANDEZ M, HORCAJADA JP, et al. Azithromycin in the treatment of COVID-19: a review. Expert Review of Anti-infective Therapy. 2020;19(2):147-63.

5. FERREIRA EO, PENNA B, YATES EA. Should we be worried about Clostridioides difficile during the SARS-CoV2 pandemic? Frontiers in Microbiology. 2020;11.

6. BIGNARDI GE. Risk factors for Clostridium difficile infection. Journal of Hospital Infections. 1998;40:1-15.

7. CALU V, TOMA EA, ENCIU O, MIRON A. Clostridium difficile infection and colorectal surgery: is there any risk? Medicina. 2019;55:683.

8. RAWSON TM, MOORE LSP, ZHU N, RANGANATHAN N, SKOLIMOWSKA K, GILCHRIST M, et al. Bacterial and fungal co-infection in individuals with coronavirus: A rapid review to support COVID-19 antimicrobial prescribing. Clin Infect Dis. 2020;3;71(9):2459-68.

9. CROBACH MJT, PLANCHE T, ECKERT C, BARBUT F, TERVEER EM, DEKKERS OM, et al. European Society of Clinical Microbiology and infectious Diseases: update of the diagnostic guidance document for Clostridium difficile infection. Clin Microbiol Infect. 2016;22(s4):s63-s81.

10. European Centre for Disease Prevention and Control. European Surveillance of Clostridium difficile infections. Surveillance protocol version 2.2. Stockholm: ECDC. 2015.

11. MCDONALD LC, GERDING DN, JOHNSON S, BAKKEN JS, CARROLL KC, COFFIN SE, et al. Clinical Practice Guidelines for Clostridium difficile Infection in Adults and Children: 2017 Update by the Infectious Diseases Society of America (IDSA) and Society for Healthcare Epidemiology of America (SHEA). CID. 2018;66(7):e1-e48.

12. GRANATA G, BARTOLONI A, CODELUPPI M, CONTADINI I, CRISTINI F, FANTONI M, et al. The burden of Clostridioides diffcile infection during the COVID-19 Pandemic: A Retrospective Case-Control Study in Italian Hospitals (CloVid). J. Clin. Med. 2020; 9:3855.

13. SANDHU A, TILLOTSON G, POLISTICO J, SALIMNIA H, CRANIS M, MOSHOS J, et al. Clostridiodes difficile in COVID-19 Patients, Detroit, Michigan, USA, March-April 2020. Emerging Infectious Diseases. 2020; 26:9.

14. LANGFORD BJ, SO M, RAYBARDHAN S, LEUNG V, WESTWOOD D, MACFADDEN DR, et al. Bacterial co-infection and secondary infection in patients with COVID-19: a living rapid review and meta-analysis. Clin Microbiol Infect. 2020; 26:1622-9.

Received $20^{\text {th }}$ April 2021 